DOE/OR/22160 - T/6

IITRI Project C06787 QAPP

U.S. DoE Contract Number DE-AC05-930R22160

\title{
Demonstration Testing and Evaluation of In Situ Heating of Soil
}

Quality Assurance Project Plan

Submitted to

Johnny Moore

U. S. Department of Energy Oak Ridge Operations Office

P. O. Box 2001

Oak Ridge, Tennessee 37831

Prepared by

IIT Research Institute

10 West 35th Street

Chicago, Illinois 60616

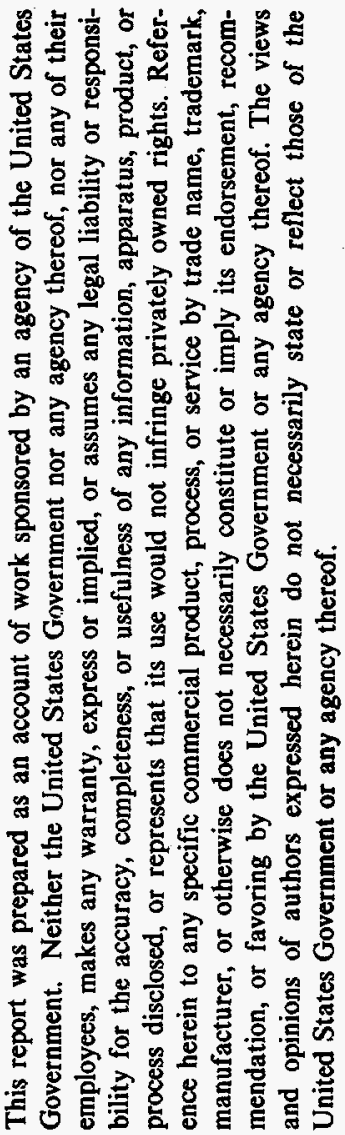

January 1995

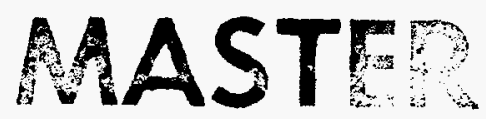




\section{DISCLAIMER}

Portions of this document may be illegible in electronic image products. Images are produced from the best available original document. 
IITRI C06787 QAPP

Section No.: Foreword

Revision: 0

Date: January 1995

Page 1 of 1

FOREWORD

This document describes the Quality Assurance Project Plan (QAPP) for IITRI Project C06787 entitled, "Demonstration Testing and Evaluation of In Situ Heating of Soil." A work plan for the above mentioned work was previously submitted ${ }^{1}$. This QAPP describes the sampling and analysis of soil core-samples obtained from the K-25 Site where an in-situ heating and soil decontamination demonstration experiment will be performed. Soil samples taken before and after the experiment will be analyzed for selected volatile organic compounds. The Work Plan mentioned above provides a complete description of the demonstration site, the soil sampling plan, test plan, etc.

Respectfully submitted,

IIT Research Institute

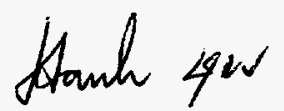

Harsh Dev

Science Advisor

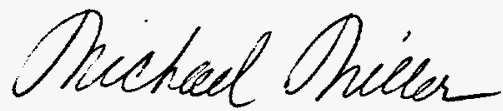

Michael Miller

Research Chemist

Approved:

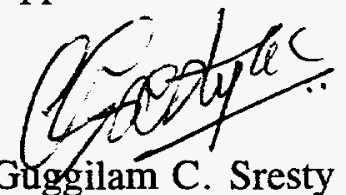

Manger

Energy and Environmental Sciences 
IITRI C06787 QAPP

Section No.: Contents

Revision: 0

Date: January 1995

Page: 1 of 2

TABLE OF CONTENTS

Section

Name

Title Page

0

Foreword

Cont.

1

2

3

4

5

6

7

8

9

10
Table of Contents

Project Description

Quality Assurance Objectives

Soil Sampling

Analytical Procedures and Calibration

Data Reduction, Validation, and Reporting

Internal Quality Control Checks

Performance and System Audits

Calculation of Data Quality Indicators

Corrective Actions Procedure

References
Pages Revision Date

$\begin{array}{lll}1 & 0 & 1 / 95 \\ 1 & 0 & 1 / 95 \\ 2 & 0 & 1 / 95 \\ & & \\ 2 & 0 & 1 / 95 \\ 7 & 0 & 1 / 95 \\ 2 & 0 & 1 / 95 \\ 16 & 0 & 1 / 95 \\ & & \\ 12 & 0 & 1 / 95 \\ 5 & 0 & 1 / 95 \\ 1 & 0 & 1 / 95 \\ 4 & 0 & 1 / 95 \\ 2 & 0 & 1 / 95 \\ 1 & 0 & 1 / 95\end{array}$


IITRI C06787 QAPP

Section No.: Contents

Revision: 0

Date: January 1995

Page: 2 of 2

LIST OF FIGURES AND TABLES

\section{Figure Name}

1 Map showing the Location of the Demonstration Site

2 Conceptual Site Layout

3 Borehole layout and Pre-Demonstration Soil Sampling Plan

4 Post-Demonstration Soil Sampling Locations (Preliminary)

$5 \quad$ Sample Log Report

Table Name

1 Volatile Hydrocarbons Found in Boreholes 71, 75, 76, 80

2 Concentration of Volatile Organics, ppb

3 Quality Assurance Objective

$4 \quad$ List of Analytes and Standards

$5 \quad$ Frequency of Blank and Duplicate Samples

6 Control Limits and Corrective Actions for VOC Analyses in Soils and Liquids

$\begin{array}{cr}\text { Section } & \quad \text { Page } \\ 2 & 3 \text { of } 8 \\ 2 & 4 \text { of } 8 \\ 3 & 2 \text { of } 6 \\ 3 & 4 \text { of } 6 \\ 3 & 6 \text { of } 6\end{array}$

Section Page

$2 \quad 2$ of 8

25 of 8

27 of 8

43 of 8

$6 \quad 1$ of 4

92 of 2

QA Project Plan Distribution List

\section{Name}

Mr. Guggilam Sresty

Mr. Michael Miller

Mr. Harsh Dev

Mr. Ronald A. Boyne

Mr. Johnny Moore

Mr. Frank Van Ryn
Title

IITRI, Project Manager

IITRI, Task Manager

IITRI, Task Manager

IITRI, QA Manager

DoE, Project Manager

MMES 
IITRI C06787 QAPP

Section No.: 1

Revision: 0

Date: January 1995

Page: 1 of 2

SECTION 1

PROJECT DESCRIPTION

The main objective of the project is to demonstrate the removal of volatile organic contaminants from clayey soil by in situ heating to a temperature range of $85^{\circ}$ to $95^{\circ} \mathrm{C}$. In situ heating will be accomplished by energizing an electrode array, buried in the soil, by $60 \mathrm{~Hz}$ line power. This electromagnetic (EM) heating system will raise the soil temperature thus increasing the vapor pressure of the spilled organic chemicals as well as that of native water. Gas collection wells placed in the heated zone will be used to collect and remove the contaminant vapors.

This in situ decontamination method depends upon the following factors to achieve a good and economic removal of contaminants from the soil:

- ability to enhance air sweep through the heated soil volume,

- ability to enhance volatilization of contaminants,

- $\quad$ energy consumption.

The relative improvement in the first 2 factors listed above will be assessed by making measurements of air flow versus applied vacuum and analysis of the effluent gas stream for the contaminants. Electrical energy consumption will be determined by watt-hour meters.

The actual efficacy of the process will be determined by comparing the residual concentration of contaminants with the initial pre-demonstration concentration. It is planned to take numerous soil core-samples both before and after the demonstration experiment. The VOCs of interest are, in general: BTEX, ketones, and various chlorinated hydrocarbons derived from methane, ethane, and ethylene. The soil samples will be analyzed for the contaminants listed in Section 2. The percentage removal of the individual contaminants will be determined by 
IITRI C06787 QAPP

Section No.: 1

Revision: 0

Date: January 1995

Page: 2 of 2

comparing the initial and final average concentration as well as by performing an analysis of variance.

The data to be gathered in this project are broadly divided into three groups:

- soil temperature and electrical power consumption data,

- Pre- and post-demonstration contaminant concentration data,

- Vacuum, air flow rate, humidity, and contaminant concentration in the effluent air stream.

This QA/QC plan addresses pre- and post-demonstration soil sampling and analyses. A later modification of this document will address the sampling and analysis of gaseous effluent concentration.

This is being done in order to expedite the system installation activities during which the pre-demonstration soil samples will be obtained. The gaseous effluents will be sampled during system operation which will occur in the April 1995 time frame. 
IITRI C06787 QAPP

Section No.: 2

Revision: 0

Date: January 1995

Page: 1 of 8

SECTION 2

QUALITY ASSURANCE OBJECTIVES

The purpose of the analytical effort is to quantify the concentration of volatile organic chemicals (VOCs) which might be present in the soil at the demonstration site. It is expected that as a result of heating the soil to a temperature of $70^{\circ}$ to $95^{\circ} \mathrm{C}$ range, approximately 90 percent of the VOCs will be removed. Thus the analytical methods should be able to analyze the initial concentration of VOCs as well as one-tenth of the initial levels.

The soil samples will be analyzed by EPA's standard method 8260 published in SW846. This method is comprised of a purge and trap procedure followed by gas chromatographic/mass spectrometric separation and detection of the volatile contaminants. The purge and trap procedure is used to separate the contaminants from the soil by passing a purge gas through the solid soil sample. The components separated from the soil are temporarily stored on adsorption columns. Once the purging is complete, the adsorbed material is desorbed and directly introduced into a GC/MS system for separation, detection and analysis. The GC/MS will be operated in the selected-ion-monitoring mode (SIM) in order to achieve the reduced detections limits required for the post treatment samples.

Table 1 summarizes the analytical results of prior soil samples obtained from Borehole Nos. $71,75,76$, and 80 . This table contains data on only those VOCs which were found above the detection limit achieved by the lab using USEPA Standard Method 624. These results present the range of concentrations found in the four boreholes which are located near the area which will be heated during this demonstration. Figures 1 and 2 illustrate the general site and the immediate area of the demonstration. Among the four holes mentioned above, the nearest one is approximately $25 \mathrm{ft}$. from one edge of the treatment zone. 
IITRI C06787 QAPP

Section No.: 2

Revision: 0

Date: January 1995

Page: 2 of 8

\begin{tabular}{|c|c|}
\hline Contaminants & $\begin{array}{c}\text { Concentration } \\
\text { Range, ppb }\end{array}$ \\
\hline \multicolumn{2}{|l|}{ Hydrocarbons } \\
\hline Acetone & $15-26,000$ \\
\hline 2-Butanone & $10-16,000$ \\
\hline Ethyl Benzene & $15-180$ \\
\hline Toluene & $140-2200$ \\
\hline 2-methyl-2-penatanone & $15-25$ \\
\hline Benzene & Up to 6 \\
\hline Carbon Disulfide & Up to 7 \\
\hline \multicolumn{2}{|l|}{ Chlorinated Hydrocarbons } \\
\hline Methylene Chloride & $5-40$ \\
\hline Tetrachloroethene & $25-130$ \\
\hline 1,1,1-Trichloroethane & $5-25$ \\
\hline 1,1,2-Trichloroethane & $10-90$ \\
\hline Trichloroethene & $20-400$ \\
\hline 1,1-Dichloroethane & $15-60$ \\
\hline 1,2-Dichloroethane & $5-30$ \\
\hline $1,1,2,2$-Trichloroethane & Up to 15 \\
\hline \multicolumn{2}{|c|}{$\begin{array}{l}\text { * Only those found at or above detection limit. } \\
\text { Based on preliminary data, Reference } 3 \text {. }\end{array}$} \\
\hline
\end{tabular}




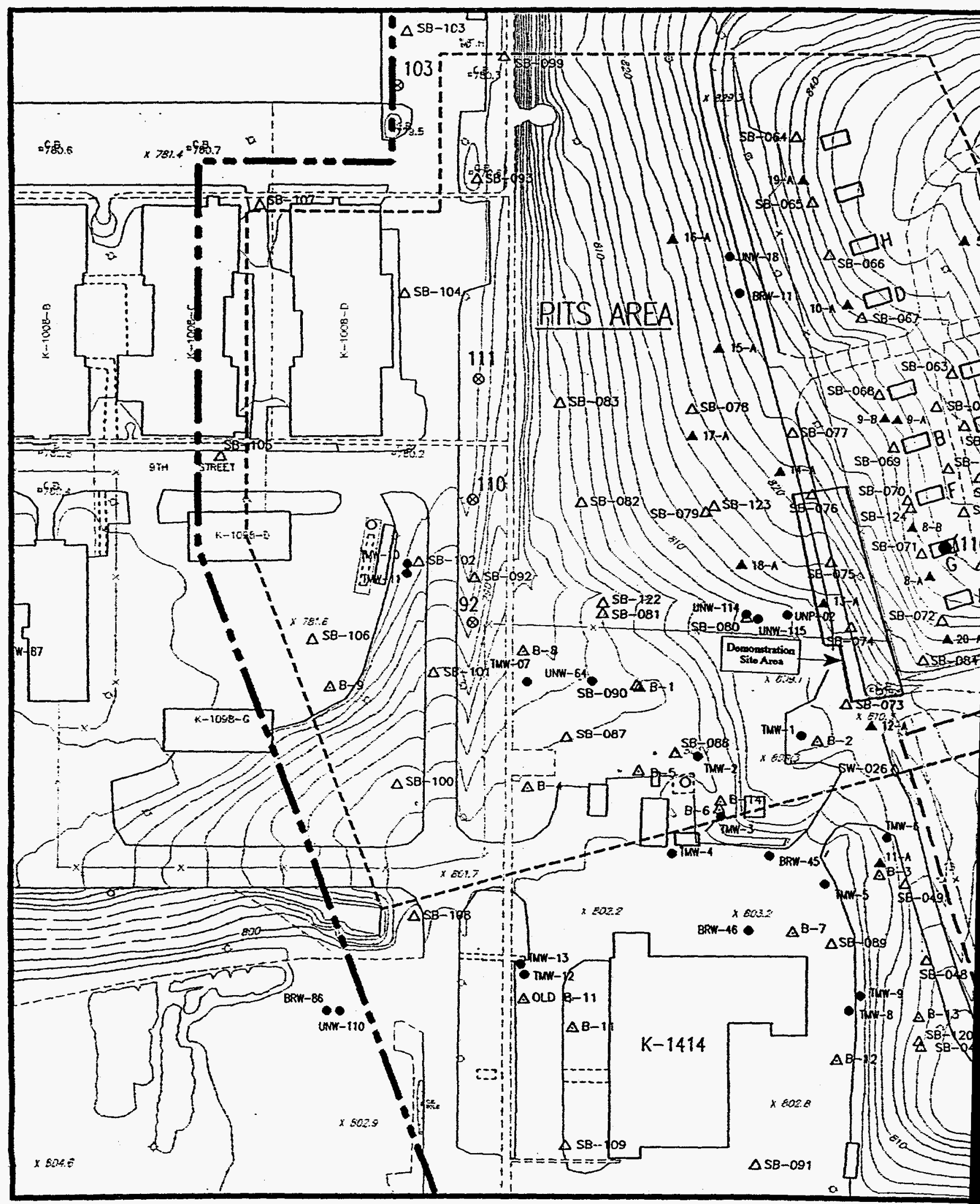

Figure 1. Map showing the Location of the Demonstration Site. 
IITRI C06787 QAPP

Section No.: 2

Revision: 0

Date: January 1995

Page: 3 of 8

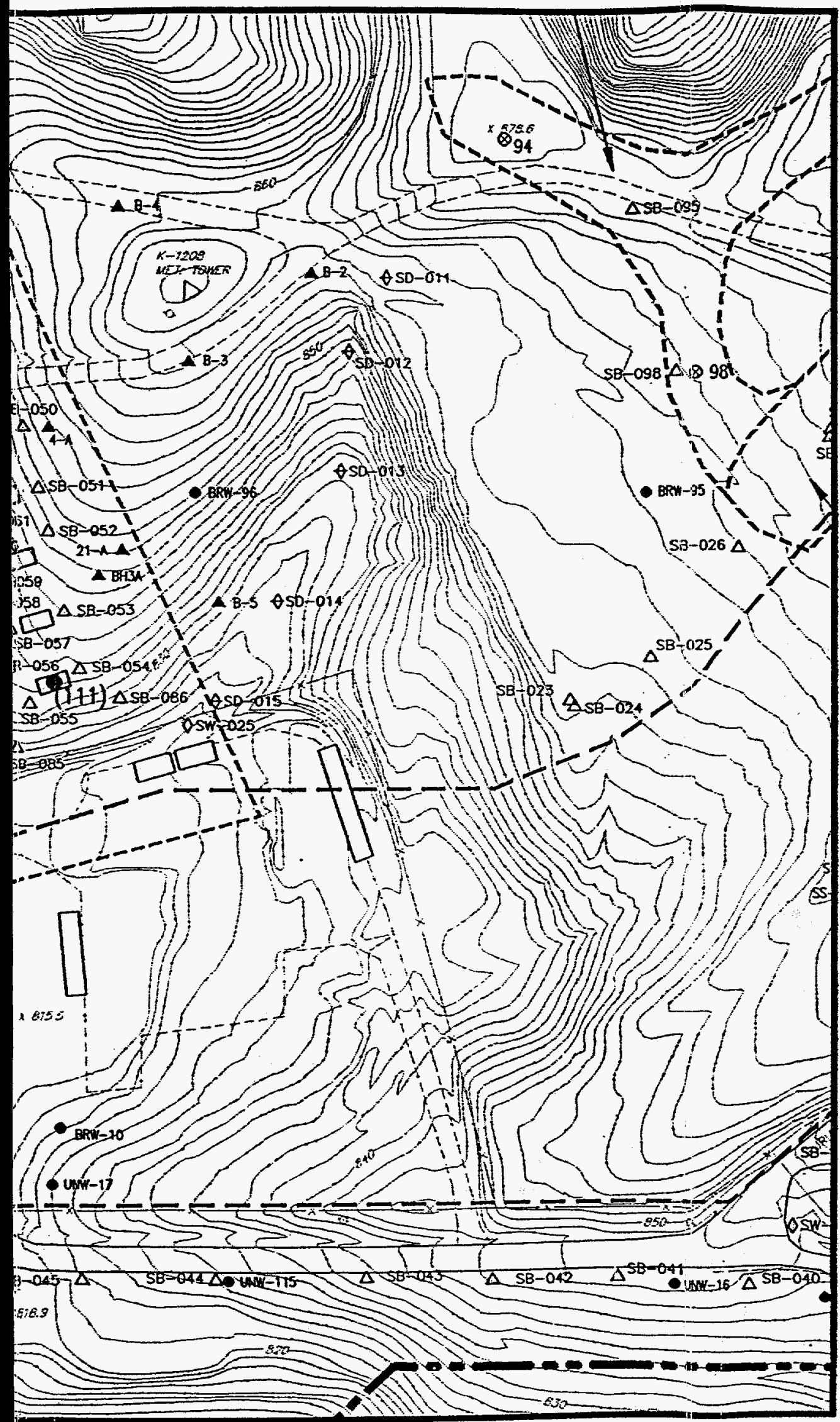

LEGEND:

\begin{tabular}{l} 
D. \\
\hline
\end{tabular}
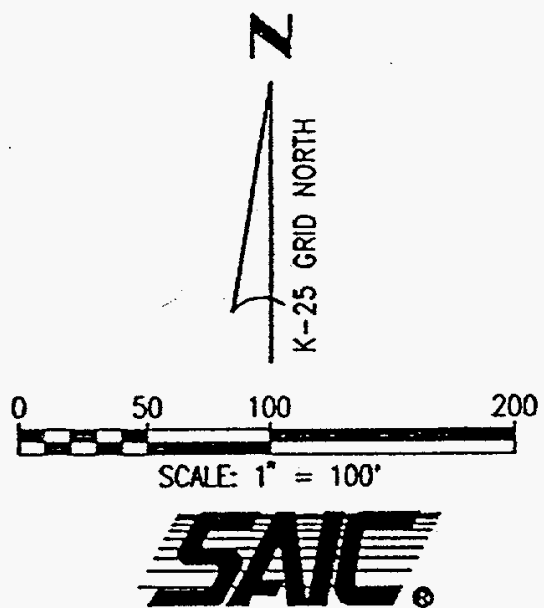

Science Applications International Corporation

$\mathrm{K}-1070 \mathrm{C} / \mathrm{D}$ CLASSIFIED BURIAL GROUNDS OAK RIDGE, TENNESSEE

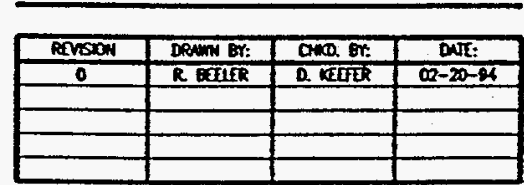

\begin{tabular}{|c|c|}
\hline 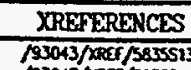 & 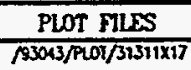 \\
\hline 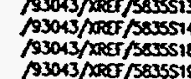 & \\
\hline
\end{tabular}

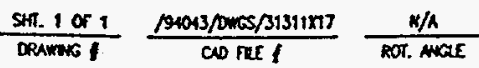




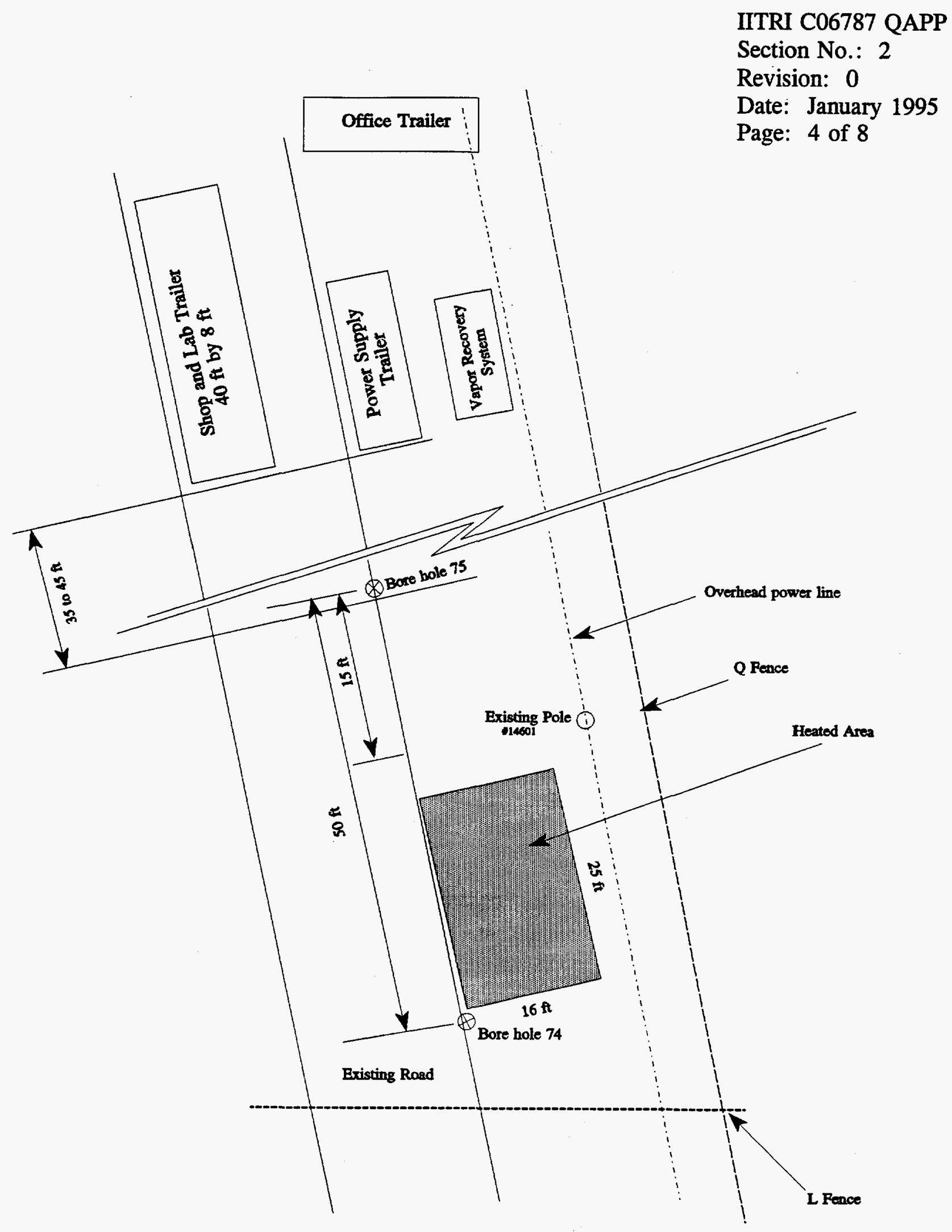

Figure 2. Conceptual Site Layout 


\begin{tabular}{|c|c|c|c|c|c|c|c|c|c|c|}
\hline & \multicolumn{3}{|c|}{ Hole Number 71} & \multicolumn{2}{|c|}{ Hole Number 75} & \multicolumn{2}{|c|}{ Hole Number 76} & \multicolumn{3}{|c|}{ Hole Number 80} \\
\hline & $\begin{array}{l}5-10 \\
\text { ft. }\end{array}$ & $\begin{array}{c}10-15 \\
\text { ft. }\end{array}$ & $\begin{array}{c}15-20 \\
\text { ft. }\end{array}$ & $\begin{array}{l}5-10 \\
\text { ft. }\end{array}$ & $\begin{array}{c}\text { 10-15 } \\
\text { ft. }\end{array}$ & $\begin{array}{l}\text { 5-10 } \\
\text { ft. }\end{array}$ & $\begin{array}{l}15-18 \\
\text { ft. }\end{array}$ & $\begin{array}{l}0-5 \\
\text { ft. }\end{array}$ & $\begin{array}{c}10-15 \\
\text { ft. }\end{array}$ & $\begin{array}{c}15-18 \\
\mathrm{ft} .\end{array}$ \\
\hline $\begin{array}{l}\text { Total volatiles, } \\
\text { ppb }\end{array}$ & 5300 & 29500 & 54900 & 6900 & 6600 & 20 & 390 & 30 & 5900 & 4200 \\
\hline $\begin{array}{l}\text { Total Chlorinated } \\
\text { Volatile HCs, ppb }\end{array}$ & 20 & 1100 & 4200 & 75 & 700 & 0 & 210 & 10 & 120 & 540 \\
\hline
\end{tabular}


IITRI C06787 QAPP

Section No.: 2

Revision: 0

Date: January 1995

Page: 6 of 8

The results of actual concentration of VOCs found in each of the four boreholes are summarized in Table 2. This shows that samples from Borehole 75 had total VOC concentrations in the range of 6,500 to $7,000 \mathrm{ppb}$.

The concentration of specific VOCs listed in Table 1 show that there are several compounds with concentrations near the published detection limit of Method 8260. In the full scan mode, this GC/MS method has a nominal detection limit of $5-100 \mathrm{ppb}$ depending upon the specific compound. However, in the single ion monitoring (SIM) mode the detection limit will be substantially lowered. Although Method 8260 has been designed for the analysis of over $\underline{60}$ VOCs, we will be working with only 15 compounds. Thus it will be possible to scan for these 15 in the SIM mode of operation and obtain a lower detection limit for most of the compounds listed in Table 1. However, there are some compounds which may still exhibit a high detection limit even in the SIM mode due to poor extraction efficiency in the purge and trap device. These compounds tend to be highly soluble in water or exhibit strong adsorption characteristics which explains the poor extraction efficiency. These compounds are: acetone, 2-butanone, carbon disulfide, and 4-methyl-2-pentanone. The published estimates of quantitation limits for these compounds when analyzed by Method 8260 are $100 \mathrm{ppb}$ for the first three compounds above and $50 \mathrm{ppb}$ for the last compound mentioned above. By comparison with actual concentrations listed in Table 1, it is possible that the detection limits achieved for carbon disulfide and 4-methyl-2-pentanone may not be adequate.

It is expected that approximately $90 \%$ reduction of the VOCs will occur upon heating and vacuum-removal of the vent gases. Thus, the post-demonstration soils may have VOC concentrations one-tenth of those observed in the pre-demonstration samples. Using data in Table 1, it is estimated that many VOCs will be in the range of $0.5 \mathrm{ppb}$ to $2600 \mathrm{ppb}$ in the post demonstration samples. Thus, the detection limit for post-demonstration samples should be $0.5 \mathrm{ppb}$ or less. It is possible that this limit will not be achieved for the water soluble ketones, 


\begin{tabular}{|c|c|c|c|c|c|}
\hline \multicolumn{6}{|c|}{$\begin{array}{c}\text { Table 3. Quality Assurance Objective } \\
\text { (All Matrix are Pre- or Post-Demonstration Soil) }\end{array}$} \\
\hline Measurement & $\begin{array}{l}\text { Precision } \\
\text { as } \mathbf{R P D}^{\mathrm{a}}\end{array}$ & $\begin{array}{l}\text { Accuracy as } \\
\text { Percent Recovery } \\
\text { From Matrix Spike }\end{array}$ & Completeness & $\begin{array}{l}\text { EQL } \\
(\mathbf{p p b})\end{array}$ & Method \\
\hline Moisture & \pm 10 & $90 \pm 15$ & 95 & $0.3 \%$ & Per QAPjP \\
\hline Ethyl Benzene & 23 & $90 \pm 15$ & 90 & $.5-5$ & 8260 \\
\hline Toluene & 23 & $90 \pm 15$ & 90 & $.5-5$ & 8260 \\
\hline Benzene & 23 & $90 \pm 15$ & 90 & $.5-5$ & 8260 \\
\hline Methylene Chloride & 23 & $90 \pm 15$ & 90 & $.5-5$ & 8260 \\
\hline Tetrachloroethene & 23 & $90 \pm 15$ & 90 & $.5-5$ & 8260 \\
\hline 1,1,1-Trichloroethane & 23 & $90 \pm 15$ & 90 & $.5-5$ & 8260 \\
\hline 1,1,2-Trichloroethane & 23 & $90 \pm 15$ & 90 & $.5-5$ & 8260 \\
\hline Trichloroethene & 23 & $90 \pm 15$ & 90 & $.5-5$ & 8260 \\
\hline 1,1-Dichloroethane & 23 & $90 \pm 15$ & 90 & $.5-5$ & 8260 \\
\hline 1,2-Dichloroethane & 23 & $90 \pm 15$ & 90 & $.5-5$ & 8260 \\
\hline 1,1,2,2-Tetrachloroethane & 23 & $90 \pm 15$ & 90 & $.5-5$ & 8260 \\
\hline Acetone & 25 & $90 \pm 15$ & 90 & $10-100$ & 8260 \\
\hline 2-Butanone & 25 & $90 \pm 15$ & 90 & $10-100$ & 8260 \\
\hline 4-Methyl-2-pentanone & 25 & $90 \pm 15$ & 90 & $5-50$ & 8260 \\
\hline Carbon Disulfide & 25 & $90 \pm 15$ & 90 & $10-100$ & 8260 \\
\hline \multicolumn{6}{|c|}{$\begin{array}{l}\text { RPD }=\text { Relative Percent Difference } \\
\text { EQL }=\text { Estimated Quantitation Limit (Matrix dependent) } \\
\text { a }\end{array}$} \\
\hline
\end{tabular}


IITRI C06787 QAPP

Section No.: 2

Revision: 0

Date: January 1995

Page: 8 of 8

and carbon disulfide. Table 3 provides a list of Quality Assurance objectives for each of the measurements.

It is essential that high degree of analytical accuracy and low detection limits in the soil be achieved in order to make statistically supportable conclusions regarding the affect of in situ soil heating on the removal of contaminants. Thus, achieving a detection limit which is onetenth to one-fifteenth of the initial soil concentration would be necessary if 90 percent removal of contaminants is to be demonstrated. By the same token, it will be necessary to minimize variation in detection limit from sample to sample.

High degree of accuracy and precision of individual soil samples is necessary. If the initial data scatter is high, then it will be difficult to differentiate the variance in the initial data from any affect produced by the soil heating. If the analysis of field duplicates shows a high variability of concentration, e.g., a variation of 2 or 5 between duplicates, then it will be important to duplicate nearly all field soil sample analysis. 
IITRI C06787 QAPP

Section No.: 3

Revision: 0

Date: January 1995

Page: 1 of 6

SECTION 3

SOIL SAMPLING

\section{Soil Sampling Plan}

Soil Samples will be obtained from the volume of earth which will be heated. The propose of soil sampling is to determine the concentration of volatile organic contaminants initially present in the soil, and by comparison with post-demonstration soil sample analysis, determine the reduction in contaminants as a result of in situ heating.

Soil samples will be obtained while drilling boreholes necessary for the installation of the in situ heating system. A total of 43 boreholes are required for the installation of various components of the decontamination system. These components are: electrodes for energy input; gas wells for vapor collection; and thermowells for monitoring soil temperature. The borehole layout is illustrated in Figure 3. There are nine boreholes from which 27 soil samples will be obtained. Soil core will be obtained in a split spoon core barrel lined with stainless steel sample liners. The diameter of soil cores will be 1-4 in. and length will be $2 \mathrm{ft}$. The split spoon will be lined with four 6-in. liners. Soil will be sampled from three different sampling intervals from every borehole that is sampled.

Attempts will be made to obtain soil samples from three different planes below the soil surfaces. Preliminary sampling intervals shall be: $1-3 \mathrm{ft}$., $8-10 \mathrm{ft}$., $15-17 \mathrm{ft}$. The actual depth interval to be sampled will be finalized after making few of the boreholes indicated in Figure 3 and assessing the condition of the deposit in terms of contaminant location, lithology, proximity of water table to the 20 -ft. depth range. It is highly desirable to perform the heating experiment in the unsaturated zone and to have the unsaturated zone extend below the heated volume by at least $8 \mathrm{ft}$. 
IITRI C06787 QAPP

Section No.: 3

Revision: 0

Date: January 1995

Page: 2 of 6

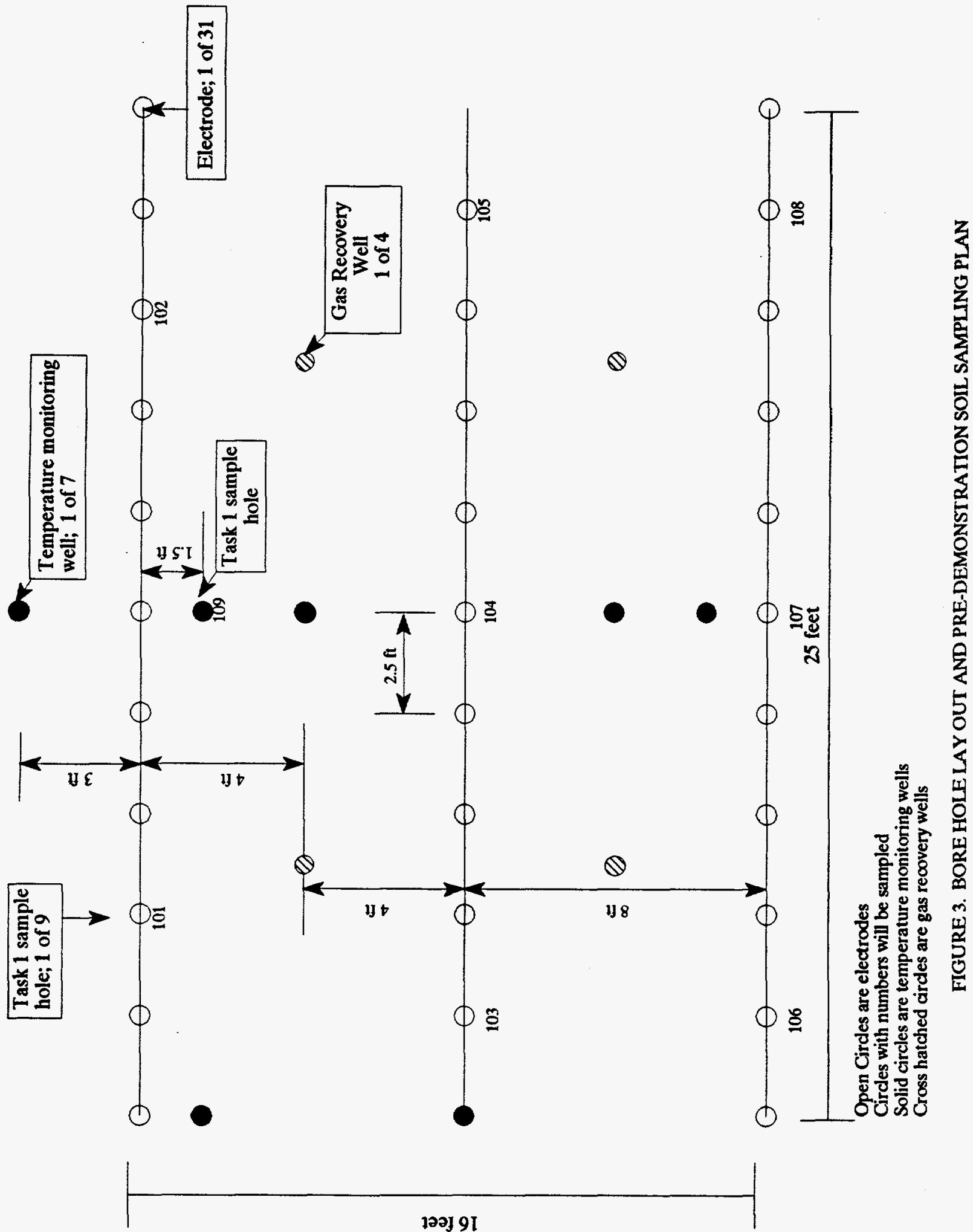


IITRI C06787 QAPP

Section No.: ' 3

Revision: 0

Date: January 1995

Page: 3 of 6

The location of the boreholes to be sampled prior to the demonstration is designated by numbers 101 through 109. From these nine holes 27 soil samples in 108 6-in. long liners will be obtained.

A preliminary post-demonstration soil sampling plan is illustrated in Figure 4. This plan will be reviewed in light of the soil temperature distribution prior to actual sampling of soil.

\section{Soil Sampling Procedure}

Soil samples will be obtained in a split spoon sampler while drilling boreholes with a hollow stem auger. The split spoon will be lined with four six-in. long pieces of a stainless steel liner. Cores will be retrieved inside the liners and transported to the laboratory inside the liners. Teflon or Tedlar lined end caps will be applied to both ends of the liners. A sample label will be affixed to each liner. Sample label will have the following information: date, site name, IITRI Project Number, borehole number, depth interval, liner sequence number inside the split spoon, and name of sampling personnel.

The capped liner will be placed in a ziploc bag, and stored in an ice-cooler. The sample cooler will be shipped to the laboratory at the end of every day. The cooler will be maintained at or below $4^{\circ} \mathrm{C}$ by means of ice or dry ice.

\section{Equipment Cleaning Procedure}

All split spoon liners will be cleaned and sealed in aluminum foil until ready for use. It is recommended that as far as possible this should be done in the laboratory. The following procedure will be used for cleaning of the sample liners:

- $\quad$ Clean with potable water and laboratory detergent using a brush if necessary to remove particulate matter and surface films. Tap water may be used if it is known that it is not ground-water or stored in a cistern, storage or other tanks. 
IITRI C06787 QAPP

Section No.: 3

Revision: 0

Date: January 1995

Page: 4 of 6

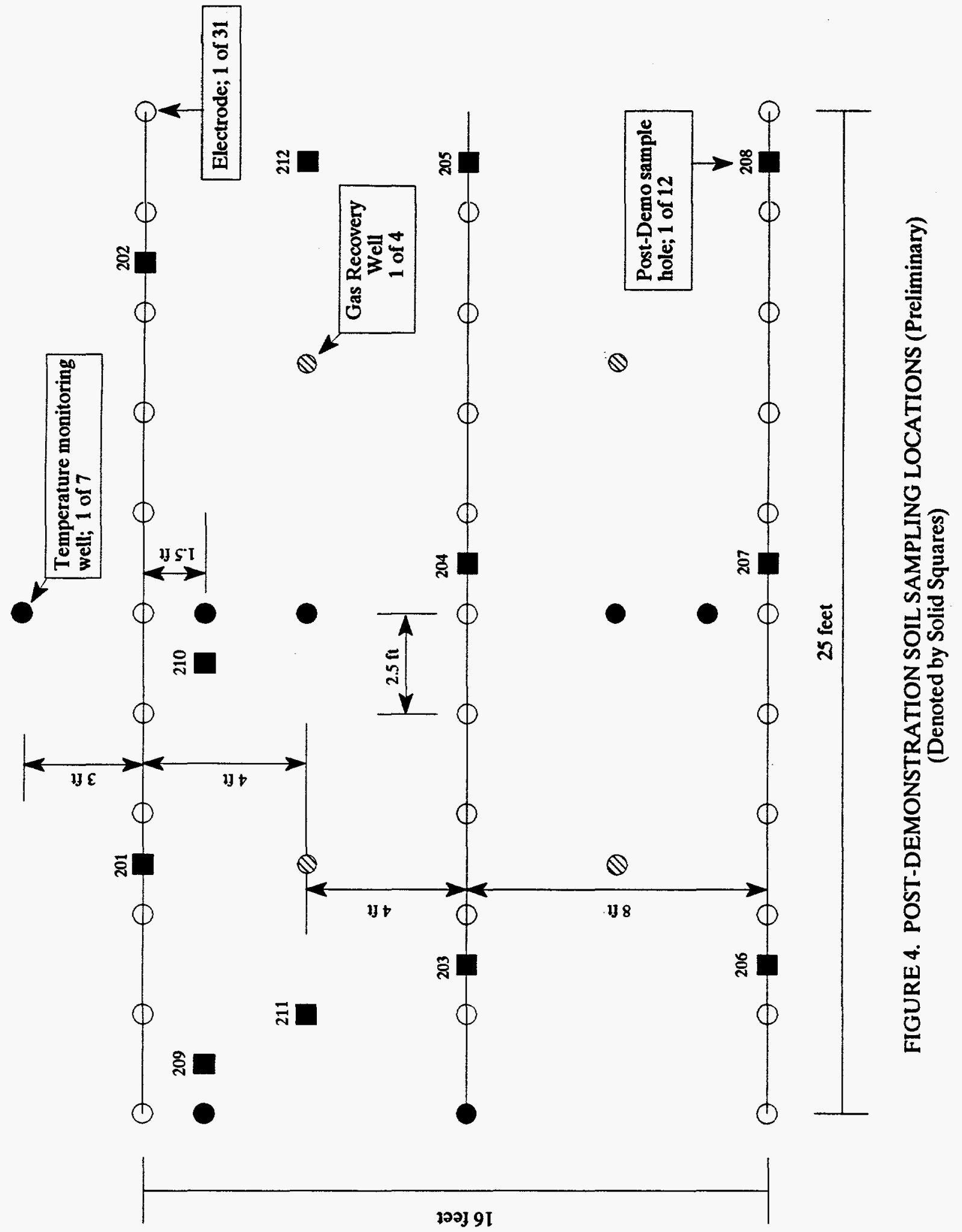


IITRI C06787 QAPP

Section No.: 3

Revision: 0

Date: January 1995

Page: 5 of 6

- $\quad$ Rinse thoroughly with potable water.

- $\quad$ Rinse thoroughly with deionized water.

- $\quad$ Rinse twice with isopropanol (pesticide grade).

- $\quad$ Rinse thoroughly with organic-free water or distilled water.

- $\quad$ Air dry as long as possible.

- Wrap with aluminum foil.

The same procedures may be used for cleaning of the split spoon, core-barrel, and hollow stem auger between sample boreholes. If cleaning in the field, store-bought distilled water may be substituted for both tap water and deionized water ${ }^{4}$

\section{Sample Log}

A Sample Log Report will be filled for each shipping container sent to the laboratory. Because shipments will be made via public carriers (e.g., overnight delivery services) complete chain of sample custody cannot be maintained. But nevertheless the Sample Log Reports should be completed by project personnel at both origin and destination. A sample log report is shown in Figure 5.

\section{Laboratory Storage of Soil Samples}

The sealed soil sample sleeves will be stored in a cold room or a cooler kept at $4^{\circ} \mathrm{C}$. Once the soil sample sleeve is opened for analysis, the soil shall be transferred to a clean jar and stored in a $4^{\circ} \mathrm{C}$ environment. 
Section No.: 3

Revision: 0

Date: January 1995

Page: 6 of 6

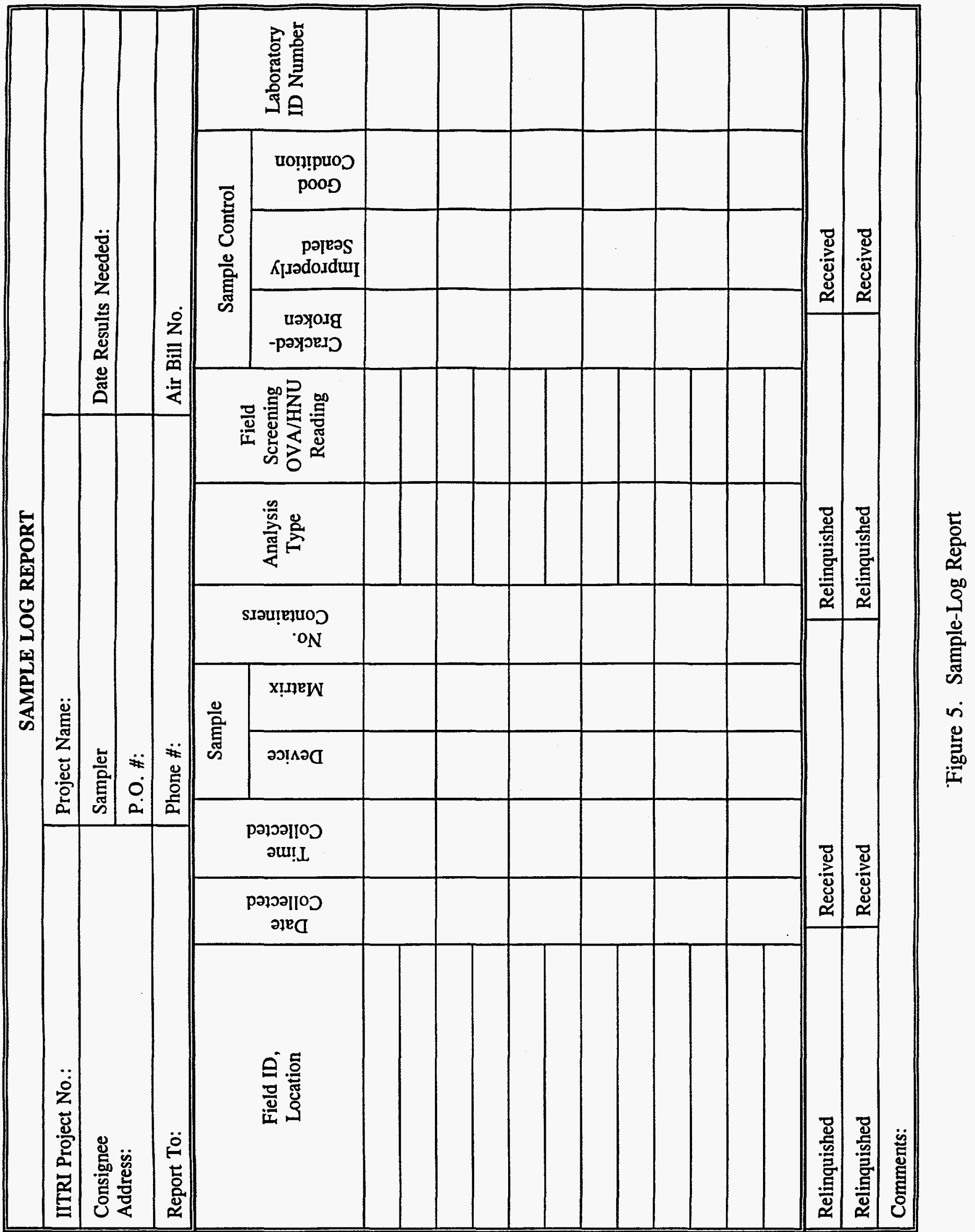


IITRI C06787 QAPP

Section No.: 4

Revision: 0

Date: January 1995

Page: 1 of 8

SECTION 4

ANALYTICAL PROCEDURES AND CALIBRATION

\subsection{INTRODUCTION}

Soil samples obtained from the field will be analyzed for volatile organic chemicals by USEPA Standard Method 8260 published in SW846².

It is envisioned that the samples will be sent by IITRI to a commercial laboratory for analysis. Among the samples sent to the laboratory IITRI will introduce QA/QC samples which will be used to assess the performance of the commercial laboratory. This section briefly describes the procedures used for the preparation of the required standards, moisture determination and the calibration procedure.

In the event that IITRI decides to perform the sample analysis in-house, a brief description of the equipment is given in Section 4.4.1. It should be noted that IITRI has proposed the use of a Ion Trap Mass spectrometer interfaced to a Varian gas chromatograph. If samples are analyzed by IITRI, then the soil moisture will be determined as per procedure given in Section 4.3. Some of the reasons why IITRI may decide to perform analysis in house are:

- Unacceptably long sample turn-around time from a commercial lab.

- Lab's inability to perform extra QA/QC procedures which are normally not performed by commercial labs when performing analysis by Method 8260 .

- Labs approach for the analysis of high concentration samples. If dilution is used, then this can raise the detection limit leading to difficulties in the statistical analysis of the data. 
IITRI C06787 QAPP

Section No.: 4

Revision: 0

Date: January 1995

Page: 2 of 8

\subsection{PREPARATION OF STANDARD SOLUTIONS}

Three types of standard solutions will be required in this project for spiking and calibration purposes. Preparation of each of these standard solutions is described below.

\subsubsection{Preparation of Surrogate Standards}

A surrogate standard spiking solution at a concentration of $250 \mu \mathrm{g} / 10 \mathrm{~mL}$ will be prepared from a stock surrogate solution. The stock standard will be diluted in a volumetric flask using purge and trap (P\&T) grade methanol as the solvent. The projected surrogate standards used to represent the contaminants (analytes) are toluene- $\mathrm{d}_{8}, 4$-bromofluorobenzene and 1,2-dichloroethane- $d_{4}$. A list of surrogate standards to be used for the selected analytes is given in Table 4. Each sample undergoing GC/MS analysis will be spiked with $10 \mu \mathrm{L}$ of this surrogate spiking solution prior to analysis.

To prepare the high concentration stock surrogate standard solution, several microliters of each of the standards will be accurately weighed into a $10 \mathrm{~mL}$ volumetric flask containing $\sim 9.8 \mathrm{~mL}$ of $\mathrm{P} \& \mathrm{~T}$ grade methanol. Once all surrogates have been added to the flask the volume will be adjusted to the $10 \mathrm{~mL}$ level with additional P\&T methanol. Each of the surrogate standards will be weighed to an accuracy of $0.1 \mathrm{mg}$ using a Mettler balance. The standards will be dissolved in methanol by shaking the flask by hand. The surrogate standard solution will be sealed in screw-cap amber vials with teflon liners and stored in a refrigerator at a temperature of $-10^{\circ}$ to $-20^{\circ} \mathrm{C}$.

\subsubsection{Preparation of Internal Standard Solution}

The projected internal standards and their associated analytes used for all analyses are given in Table 4. The internal standard stock solution will be prepared using the same procedure described above for the surrogate standard solution. The spiking solution will be prepared at a concentration for $\sim 25 \mu \mathrm{g} / \mathrm{mL}$ of each internal standard compound. Each 


\begin{tabular}{|c|c|c|}
\hline Analyte & Internal Standard & Surrogate Standard \\
\hline \multicolumn{3}{|l|}{ Hydrocarbons } \\
\hline Acetone & Bromochloromethane & 1,2-Dichloroethane- $\mathrm{d}_{4}$ \\
\hline 2-Butanone & 1,4-Difluorobenzene & 4-Bromofluorobenzene \\
\hline Ethyl Benzene & Chlorobenzene- $\mathrm{d}_{5}$ & Toluene- $d_{8}$ \\
\hline Toluene & Chlorobenzene- $\mathrm{d}_{5}$ & Toluene- $\mathrm{d}_{8}$ \\
\hline 4-Methyl-2-penatanone & Chlorobenzene- $\mathrm{d}_{5}$ & Toluene- $\mathrm{d}_{8}$ \\
\hline Benzene & 1,4-Difluorobenzene & 4-Bromofluorobenzene \\
\hline Carbon disulfide & Bromochloromethane & 1,2-Dichloroethane- $\mathrm{d}_{4}$ \\
\hline \multicolumn{3}{|l|}{ Chlorinated Hydrocarbons } \\
\hline Methylene Chloride & Bromochloromethane & 1,2-Dichloroethane- $\mathrm{d}_{4}$ \\
\hline Tetrachloroethene & Chlorobenzene- $\mathrm{d}_{5}$ & Toluene- $\mathrm{d}_{8}$ \\
\hline 1,1,1-Trichloroethane & 1,4-Difluorobenzene & 4-Bromofluorobenzene \\
\hline 1,1,2-Trichloroethane & 1,4-Difluorobenzene & 4-Bromofluorobenzene \\
\hline Trichloroethene & 1,4-Difluorobenzene & 4-Bromofluorobenzene \\
\hline 1,1-Dichloroethane & Bromochloromethane & 1,2-Dichloroethane- $\mathrm{d}_{4}$ \\
\hline 1,2-Dichloroethane & Bromochloromethane & 1,2-Dichloroethane- $\mathrm{d}_{4}$ \\
\hline 1,1,2,2-Tetrachloroethane & Chlorobenzene- $\mathrm{d}_{5}$ & Toluene- $d_{8}$ \\
\hline
\end{tabular}


IITRI C06787 QAPP

Section No.: 4

Revision: 0

Date: January 1995

Page: 4 of 8

calibration standard and sample ( 5 gram or $5 \mathrm{~mL}$ ) will be spiked with $10 \mu \mathrm{L}$ of this standard solution.

\subsubsection{Preparation of Calibration Standards}

Calibration standards containing the analytes, surrogate and internal standards will be prepared using reagent water (water which does not contain target analytes at the method detection limit [MDL] for each component) as the solvent in 50 or $100 \mathrm{~mL}$ volumetric flasks. A minimum of five different calibration standards will be prepared by dilution of a stock standard solution which is prepared in P\&T methanol as described in Section 4.2.1. One of the concentration levels will be at a concentration near, but above, the MDL. The remaining concentration levels will correspond to the expected range of concentrations found in the samples. These standards will not exceed the working range of the GC/MS system. The standards will be stored under refrigeration. Stock standards can be stored up to two months if no changes are indicated, and the diluted calibration standards must be prepared daily. All standards should be stored in septum cap vials with no headspace.

\subsubsection{Preparation of Matrix Spiking Standards}

Matrix spiking standards will be prepared from the list of target analytes presented in Table 4. At a minimum this spiking solution will contain five of these VOCs. The standard will be prepared in P\&T methanol, with each compound present at a concentration of 250 $\mu \mathrm{g} / 10.0 \mathrm{~mL}$. Ten microliters of the matrix spike solution will be added to $5 \mathrm{~mL}$ of the sample to be purged. Disregarding any dilutions, this amount is equivalent to a concentration of $\mathbf{5 0}$ $\mu \mathrm{g} / \mathrm{L}$ of each matrix spike compound. Since the mass spectrometer is going to be operated in the SIM mode, a more dilute spiking mixture may be required. This standard mixture will be stored at $-10^{\circ} \mathrm{C}$ to $-20^{\circ} \mathrm{C}$ in amber vials with Teflon-lined screw caps with a minimal headspace above the liquid level. 
IITRI C06787 QAPP

Section No.: 4

Revision: 0

Date: January 1995

Page: 5 of 8

\subsection{DETERMINATION OF SOIL MOISTURE}

The purpose of this analysis is to determine the moisture content of the soil samples prior to and after the decontamination experiments. The procedure for the determination of soil moisture is as follows. Approximately $10 \mathrm{~g}$ of the soil sample is weighed accurately in an aluminum dish using an analytical balance. The tare, gross, and net weights are recorded to the nearest $0.1 \mathrm{mg}$. The weighed dish containing the soil sample is left in a preheated oven for 16 hours. The oven temperature is set at $104^{\circ} \mathrm{C}$, and the temperature of the oven is monitored using a thermometer. At the end of 16 hours, the sample is removed from the oven and allowed to cool to room temperature in a desiccator. The weight loss is noted, and the sample is returned to the oven for an additional 1 hour. The weight loss after the second heating period is noted, and compared against the first. There should not be more than a $5 \mathrm{mg}$ weight difference in the soil weight between the first and second heating periods.

The weight loss of the soil sample will be determined as the difference between the original soil weight and the average of the dried soil weight. The weight loss of the soil expressed as percentage of the original wet-weight of the soil sample is called the soil moisture content.

\subsection{DETERMINATION OF THE CONCENTRATIONS OF THE ANALYTES IN SOIL}

The concentrations of the contaminants (analytes) in the soil samples obtained prior to and after the field demonstration experiment, and in quality control (QC) soil samples will be determined by means of a two step procedure. The first step involves the separation of the volatile analytes from the soil. The separation is accomplished in a purge and trap device as required by Method 8260 . For soil samples containing approximately less than $1000 \mathrm{ppb}$, the "low-level" procedure will be used. In this procedure approximately 1 to $5 \mathrm{gm}$ of the soil sample is placed in the purging vessel and mixed with organic-free water containing internal and surrogate standards. 
IITRI C06787 QAPP

Section No.: 4

Revision: 0

Date: January 1995

Page: 6 of 8

The "high-level" analysis is performed when the soil concentration is greater than 1000 ppb. In the high level method, approximately $4 \mathrm{gm}$. of soil are extracted with $10 \mathrm{~mL}$ of methanol. The surrogate spiking solution is added to the soil prior to extraction. Extraction is done by shaking the vial for a period of 2 minutes. $1.0 \mathrm{~mL}$ of the extract is used for analysis in a purge and trap device containing organic-free water and the appropriate surrogates.

As the analytes are purged out of the water they are stored on adsorption columns inside the purge and trap device. When the purging cycle is complete then the second step of the procedure commences. In this step the adsorption columns are rapidly heated to desorb the trapped analytes. The GC carrier gas flowing through the adsorption columns sweeps the analytes into the GC system when the analytes are separated. The GC is interfaced with a MS for detection and quantification.

\subsubsection{GC/MS Analysis of Soil if Done In-House by IITRI}

Samples obtained from the performance of field experiments at Oak Ridge will be analyzed using a Finnigan MAT Ion Trap Mass Spectrometer (ITMS) interfaced to a Varian 3400 gas chromatograph (GC). The volatile organics to be analyzed will be introduced into the GC using a Tekmar LSC3 Purge and Trap Concentrator. The data will be acquired and processed using the Finnigan PCDS software package which is installed on a Zenith 386 PC. The samples will be analyzed following the procedures described in Method 8260 of the SW846 Compendium. The procedure will be modified, as necessary, to take into account variations in the soil matrix. All the required modifications will be reported to EPA in quarterly reports, and an updated procedure will be included in the final report.

\subsubsection{Calibration of the GC/MS System}

A minimum of five different calibration standards containing each of the analytes and surrogate standards will be used for instrument calibration as required by Method 8260. The concentrations of the analytes in these standards are anticipated to be in the range of 5 to 200 
IITRI C06787 QAPP

Section No.: 4

Revision: 0

Date: January 1995

Page: 7 of 8

$\mu \mathrm{g} / \mathrm{mL}$. The concentrations are chosen to cover the expected concentration range for each of the analytes.

The calibration curve is prepared by plotting along the ordinate the area ratio of the analyte to its corresponding internal standard. The mass ratio of the analyte mass on-column to the internal standard mass on-column is plotted along the $\mathrm{x}$-axis. For an ideal system which has zero error, this curve will be a straight line with the slope equal to the relative response factor as defined by equation 1 below.

$$
R F=\left(\frac{A_{x}}{A_{i s}}\right) \div\left(\frac{I_{x}}{I_{i s}}\right)
$$

where:

$\mathrm{A}_{\mathrm{x}} \quad=$ Area of the characteristic ion for the compound being measured

$\mathrm{A}_{\mathrm{is}} \quad=$ Area of the characteristic ion for the specific internal standard

$\mathrm{I}_{\mathrm{x}} \quad=$ Amount of the compound being measured

$\mathrm{I}_{\mathrm{is}} \quad=$ Amount of the specific internal standard

However, due to the errors present in any real system, the straight line will normally not pass through the origin and therefore the actual calibration curve is obtained by fitting a linear regression line to the data plotted as described above. In this way a calibration curve is obtained for each of the analytes and the surrogate standards.

The calibration of the instrument is checked in three ways. First, a linearity check is made by running standards at the five concentration levels to make sure that when all the calibration data are plotted, the line does not exhibit any curvature, i.e., the slope of the calibration curve is constant over the entire calibration range.

The second check on calibration is to ensure that the instrument calibration does not change or drift with time and remains reproducible. This is done by daily injection of a calibration standard. The response obtained will be plotted on the full calibration curve to make 
IITRI C06787 QAPP

Section No.: 4

Revision: 0

Date: January 1995

Page: 8 of 8

sure that the daily variation in instrument response does not deviate more than $25 \%$ of the regression standard deviation about the fitted regression line. If larger than $25 \%$ deviation is noted, a new calibration curve will be developed by reinjection of the calibration standards. Each day a different calibration standard will be injected so as to check the reproducibility of the instrument responses over the entire calibration range. The third check is to monitor the RFs to ensure that a minimum RF for selected analytes (see Table 6) are achieved. This determination is performed in order to monitor the integrity of the calibration standards and the performance of the chromatographic system (e.g., injection port liner, analytical column).

The quality of each analysis of unknown samples will be assessed by calculations of the surrogate standard spike added to each sample. In addition, matrix spikes (containing representative target compounds), analytical method blanks, and column blanks will be run on a regular basis. 
IITRI C06787 QAPP

Section No.: 5

Revision: 0

Date: January 1995

Page: 1 of 4

SECTION 5

DATA REDUCTION, VALIDATION, AND REPORTING

\subsection{CALIBRATION CURVES AND DETERMINATION OF RESPONSE FACTORS}

A number of calibration standards containing the analytes, surrogate standards, and internal standards will be prepared for GC/MS analysis. Samples of the standard solutions will be analyzed using the Purge and Trap system, and calibration curves will be developed for each of the analytes and surrogate standards 5 . Calibration curves will be developed by plotting area ratios obtained from the GC/MS analyses as a function of mass ratios. In the calibration curves, the slope of the line is proportional to the response factor for the analyte. The slope becomes identically equal to the response factor should the system be error free, that is, if the intercept becomes equal to zero. A straight line will be fitted to the data points. The regression equation will be used for the quantification of the unknown samples. If the system is found to be linear, then the procedure given in Method 8260 will be used for data reduction. In this procedure, the average RF of each analyte is used for data reduction.

\subsection{CALCULATION OF ANALYTE CONCENTRATION}

In this project the analytes are:

- Hydrocarbons:

- Acetone

- 2-Butanone

- Ethyl Benzene

- Toluene

- 4-Methyl-2-pentanone

- Benzene

- Carbon disulfide

- Chlorinated Hydrocarbons:

- Methylene Chloride

- Tetrachloroethene

- 1,1,1-Trichloroethane 
IITRI C06787 QAPP

Section No.: 5

Revision: 0

Date: January 1995

Page: 2 of 4

- 1,1,2-Trichloroethane

- Trichloroethene

- 1,1-Dichloroethane

- 1,2-Dichloroethane

- 1,1,2,2-Tetrachloroethane

The projected surrogate standards are:

- 1,2-Dichloroethane- $\mathrm{d}_{4}$

- 4-Bromofluorobenzene

- Toluene- $\mathrm{d}_{8}$

The purpose of all the analyses is to determine the concentrations of the analytes in soil sample from the Oak Ridge test site.

For low-level soil samples the analyte concentration is calculated as follows:

$$
C_{\text {soil }, x}=\frac{A_{x} \cdot I_{i s}}{A_{i s} \cdot R F \cdot W_{s o i l} \cdot D} \mu g / g
$$

Where:

$$
\begin{array}{ll}
\mathrm{A}_{\mathrm{x}}, \mathrm{A}_{\mathrm{is}}, \mathrm{I}_{\mathrm{is}} & =\text { defined previously } \\
\mathrm{C}_{\text {soil, } \mathrm{x}} & =\text { concentration of analyte } \mathrm{x} \text { in soil, } \mu \mathrm{g} / \mathrm{g} \\
\mathrm{W}_{\text {soil }} & =\text { weight of soil used in P\&T unit, } \mathrm{g} \\
\mathrm{D} & =\text { dry-solids fraction in the soil } \\
\mathrm{RF} & =\text { response factor for compound being measured (see Equation 1) }
\end{array}
$$

The recovery efficiency $\eta_{s}$ of the surrogate standard from the solid sample matrix is calculated from the following equation:

$$
\eta_{s}=\frac{C_{x}}{C_{s u} \cdot V_{s u s}}
$$

Where:

$$
\begin{array}{ll}
\mathrm{C}_{\mathrm{x}}= & \text { concentration of surrogate in the analyzed sample, } \mathrm{ng} / \mu \mathrm{L} \text { or } \mu \mathrm{g} / \mathrm{mL} \\
\mathrm{C}_{\mathrm{su}}= & \text { concentration of surrogate in the surrogate spike solution, } \mu \mathrm{g} / \mu \mathrm{L} \\
\mathrm{V}_{\mathrm{sus}}= & \begin{array}{l}
\text { volume of surrogate spiking solution added to sample prior to } \mathrm{P} \& \mathrm{~T} \\
\text { extraction, } \mu \mathrm{L}
\end{array}
\end{array}
$$


IITRI C06787 QAPP

Section No.: 5

Revision: 0

Date: January 1995

Page: 3 of 4

For liquid extract samples analyzed for "high-level" (water) samples the analyte concentration is calculated using the following equation:

$$
C_{\text {soil, } x}=\frac{A_{x} \cdot I_{i s} \cdot V_{t}}{A_{i s} \cdot R F \cdot V_{0} \cdot D}
$$

Where:
$A_{x}, A_{\text {is }}, I_{\text {is }}, R F$
$=$ defined previously
$\mathrm{V}_{\mathrm{t}}$
$=$ volume of extract
$\mathrm{V}_{0}$
$=$ volume of liquid purged $(\mathrm{mL})$, taking into consideration any dilutions made
D $\quad=$ dry solids fraction in sample

\subsection{CALCULATION OF RECOVERY EFFICIENCIES}

Recovery efficiencies for each of the analytes are assumed to be the same as the recovery of the appropriate surrogate standard added to the soil or liquid sample prior to its P\&T extraction. The recovery efficiency of the surrogate standard is calculated as the amount of the surrogate standard present in the extract to the amount of the surrogate standard added to the soil or liquid sample, expressed as a percentage. The amount of the surrogate standard in the total extract is calculated using the following equation:

$$
\text { Recovery, } \eta=\frac{W_{c s}}{W_{s u}} \times 100, \%
$$

Where:

$$
\begin{array}{lll}
\mathrm{W}_{\mathrm{su}} & = & \text { amount of surrogate added to sample prior to P\&T extraction, ng } \\
\mathrm{W}_{\mathrm{cs}}= & \text { amount of surrogate in sample as analyzed by GC/MS, ng } \\
\eta & =\quad \text { recovery efficiency, } \%
\end{array}
$$


IITRI C06787 QAPP

Section No.: 5

Revision: 0

Date: January 1995

Page: 4 of 4

\subsection{DATA REDUCTION AND REPORTING}

IITRI will generate and provide all items listed below. Upon completion of this project, all the raw data and logbooks will be kept by the Quality Assurance Officer in the IITRI archives.

1. The sample identification numbers.

2. The calculated values of analytes and moisture determination.

3. If no analyte detected, report "not detected" or N.D. and give the calculated detection limit.

4. The results of duplicate analysis.

5. The percent recovery from spiked samples.

6. The results from the method blank.

7. Relative response factor for the calibration data (if internal standard method is used) or calibration curve equation with correlation coefficient of 0.98 or better.

8. The daily measurements of relative response factor (if internal standard is used) or daily calibration analysis should remain within $\pm 25 \%$ of the calibration equation.

9. Mass spectra and/or GC chromatograms for all samples and standards, including chromatograms of column performance checks.

10. Documentation on the source of the calibration standards used.

11. Any other supporting data.

\subsection{CRITERIA USED TO VALIDATE DATA}

The laboratory must obtain satisfactory results for the QA samples, duplicate, replicate, and blank samples. Standard statistical methods will be used to identify the outliers in samples from a population considered to follow an appropriate distribution. 
IITRI C06787 QAPP

Section No.: 6

Revision: 0

Date: January 1995

Page: 1 of 4

SECTION 6

INTERNAL QUALITY CONTROL CHECKS

The internal quality control checks include analysis of blank, duplicate, and replicate, field blanks, trip blanks, rinsate blanks, etc.

Table 5 provides the frequency of the type of blank, replicate and duplicate analyses that will be performed during this project. The various terms are defined below:

\begin{tabular}{||l|l||}
\hline \multicolumn{2}{|c|}{ Table 5. Frequency of Blank and Duplicate Samples } \\
\hline \multicolumn{1}{|c|}{ Sample } & \multicolumn{1}{c|}{ Frequency } \\
\hline \hline Calibration Blank & Once daily \\
\hline Reagent Blank & One in 20 samples \\
\hline Check Standard & Once daily \\
\hline Matrix & One in 20 samples \\
\hline Matrix Spike Duplicate & All matrix spikes shall be duplicated \\
\hline Soil Sample Duplicate & $\begin{array}{l}\text { At least 20\% of all samples. Preferred, } \\
100 \%\end{array}$ \\
\hline Laboratory Replicate & $\geq 20 \%$ of all extracts, but at least 5 \\
\hline Trip Blanks & $\begin{array}{l}\text { One in every batch shipped back from } \\
\text { field to lab }\end{array}$ \\
\hline Rinsate Blank & One for every day of soil sampling \\
\hline
\end{tabular}

Calibration Blank: An aliquot of the solvent used to prepare the instrument calibration standard will be treated as an unknown sample. This solution will only have the various internal standards spiked at the same concentration levels as used in unknown samples.

Reagent Blank: The various sample preparation steps will be carried out without the inclusion of the soil. 
IITRI C06787 QAPP

Section No.: 6

Revision: 0

Date: January 1995

Page: 2 of 4

Check Standard: Injection of a prepared instrument calibration standard or other known standard solution into the instrument. Analytes to be selected as per SW846 Method 8260. It should be noted that soil samples from this site that were analyzed by others showed that 3 of 5 analytes in the recommended system performance check compounds list are not present in the soil. Due to this, it may be necessary to replace the 3 absent analytes with other suitable ones.

Matrix Spike: A solution containing the analytes will be spiked onto the soil. The soil will then be carried through all the preparatory steps and analyzed to establish the percent recovery of each of the spiked analytes.

Method 8260 recommends 5 compounds be used for the matrix spike. Of these five, two are present in the soil, two are absent and one is present at very low levels. So the matrix spike compound list will have to be changed. If IITRI performs the analysis in-house, all target compounds will be in the matrix spike solution.

Matrix Spike Duplicate: Same as Matrix Spike above.

Soil Sample Duplicates: As a minimum $20 \%$ of the soil samples will be analyzed in duplicate. It is actually preferred to obtain $100 \%$ duplication of all samples. When this is done, statistical analysis of the data can be done without making assumptions about the nature of the population distribution. Attempts will be made to perform $100 \%$ duplication subject to availability of funds.

Laboratory Replicates: This refers to the repeat analysis of the prepared extract under the same instrument operating conditions.

Trip Blank: Trip blanks are sample containers filled in the laboratory with organic-free water and carried unopened during the sampling trip. It must be prepared by the laboratory supplying sample containers. It is used to identify contamination introduced from the originating laboratory. The trip blank remains with the collected samples and is analyzed along with the field samples to check residual contamination. Trip blanks are mandatory for volatile hydrocarbon analysis in water. 
IITRI C06787 QAPP

Section No.: 6

Revision: 0

Date: January 1995

Page: 3 of 4

Rinsate Blank: Rinsate blanks are generated from cleaned field sampling equipment such as augers, core barrels, tools for sample handling, etc. The cleaned items will be rinsed with organic-free water which will be collected in jars and sent to the laboratory for analysis.

\subsection{DALY CHECK OF GAS CHROMATOGRAPHY COLUMN PERFORMANCE}

The column performance check procedure described in the Analytical Procedure will be followed. Performance must meet the criteria described in the procedure. If the criteria are not met, the column will be replaced or reconditioned.

\subsection{INITIAL METHOD CALIBRATION}

A detailed multipoint calibration procedure described in the Analytical Procedure will be followed. Linear regression analysis or relative response factors will be calculated (if internal standard procedure is used). The correlation coefficient should be $\geq 0.96$ or the relative response factor should have RSD $\leq 15 \%$.

\subsection{CONTINUING VERIFICATION OF CALIBRATION}

Each working day, a mid-level calibration standard will be run to verify the initial calibration factor. If the calibration factor is not within $\pm 20 \%$ of the initial method calibration, a new multipoint calibration curve must be generated prior to any sample analysis.

\subsection{METHOD BLANK}

A laboratory blank will be run along with each set of samples. A method blank is performed by executing all of the specified extraction and cleanup steps, except for the introduction of a sample. The method blank is used to control the contamination of samples in the laboratory. 
IITRI C06787 QAPP

Section No.: 6

Revision: 0

Date: January 1995

Page: 4 of 4

\subsection{REPEAT ANALYSIS}

\subsubsection{Laboratory Replicates}

The laboratory replicate refers to the repeat analysis of an extract of the same sample under the identical analytical conditions. The replicate results are compared. Laboratory replicates will be used to estimate the analytical errors. At least $20 \%$ of the extracts will be run as laboratory duplicates.

\subsection{MATRIX EFFECT SPIKE}

A standard mixture containing the surrogate standard will be added to every soil sample, extracted, and analyzed. The percent recovery of the surrogate compound will be calculated. 
IITRI C06787 QAPP

Section No.: 7

Revision: 0

Date: January 1995

Page: 1 of 1

SECTION 7

PERFORMANCE AND SYSTEM AUDITS

The technical system audit for the program will be conducted by Guggilam Sresty, Manager of the Energy and Environmental Sciences. He will ensure that personnel assigned to various program activities possess the required qualifications, and that equipment is properly selected.

Performance of the analytical instruments used in the determination of the critical measurements is monitored at the required frequency. A strict sample analysis sequence is followed on each working day in the GC/MS laboratory. After checking the mass calibration and tune of the mass spectrometer, a calibration standard is analyzed daily and compared with the calibration curves. A similar procedure will be used in the GC laboratory. If the area response of the analyte in the injected calibration standard is within $20 \%$ of the existing calibration curve, unknown samples are analyzed. 
IITRI C06787 QAPP

Section No.: 8

Revision: 0

Date: January 1995

Page: 1 of 3

SECTION 8

\section{CALCULATION OF DATA QUALITY INDICATORS}

The concentration of the analytes in the soil samples obtained prior to and after the decontamination experiments are considered to be the critical measurements in this project, as described in Section 2. The quality of these measurements will be assessed using the following methods:

- $\quad$ Liquid QA samples will be analyzed using procedures that are the same as those employed for analysis of the soil samples. The measured concentrations of the QC samples will be compared with the actual spiked concentrations. The measured concentrations should be within $\pm 20 \%$ of the actual concentrations.

- A calibration curve for each of the analytes will be maintained continuously on the GC/MS data systems. One of the calibration standards will be injected on a daily basis, and the concentration of each of the analytes will be calculated using the existing calibration curve. The calculated concentration should be within $\pm 20 \%$ of the actual concentration. A deviation will indicate a deterioration in the system or the calibration standards.

\subsection{PRECISION}

Precision in the critical measurements will be determined by duplicate analysis of soil samples and soil extracts. At least $20 \%$ of the soil samples will be analyzed in duplicate. At least $20 \%$ of the soil extracts will be analyzed as replicate samples. It is the objective of this project to achieve a precision of $\pm 20 \%$. Data precision will be calculated using the following equation, and will be expressed as relative percent difference:

$$
R P D=[A b s(c 1-c 2) / 0.5(c I+c 2)] x 100 \%
$$

where:

$$
\text { RPD = relative percent difference }
$$


IITRI C06787 QAPP

Section No.: 8

Revision: 0

Date: January 1995

Page: 2 of 3

c1 = larger of the two observed values

c2 = smaller of the two observed values

\subsection{ACCURACY}

The accuracy of the concentration of each of the analytes in the soil extracts will be determined based on the results obtained using matrix spikes. Accuracy will estimated to be same as the recovery of the spike, and is calculated using the following equation.

$$
R=100 x[(c i-c o) / c t]
$$

where:

$$
\begin{array}{ll}
\mathrm{R} & =\text { percent recovery } \\
\mathrm{ci} & =\text { measured analyte concentration using matrix spike sample } \\
\mathrm{co} & =\text { measured analyte concentration using unspiked soil sample } \\
\mathrm{ct} & =\text { actual concentration of the spiked analyte in the matrix spike sample }
\end{array}
$$

\subsection{COMPLETENESS}

Completeness will reported as the percentage of all critical measurements made whose results are judged to be valid. It is the objective of the project to achieve a completeness value $>90 \%$. The following formula will be used to determine completeness:

$$
\% C=100 \% m \times(V / T)
$$

where:

$$
\begin{aligned}
\% \mathrm{C} & =\text { percent completeness } \\
\mathrm{V} & =\text { number of measurements judged valid } \\
\mathrm{T} & =\text { total number of measurements }
\end{aligned}
$$


IITRI C06787 QAPP

Section No.: 8

Revision: 0

Date: January 1995

Page: 3 of 3

\subsection{METHOD DETECTION LIMIT}

The detection limit for each of the analytes will be determined by estimating the noise level for the analyte in each sample extract. The noise level in the chromatogram adjacent to the retention time of the analyte will be determined. Objectives for method detection limit are listed in Table 3. 
IITRI C06787 QAPP

Section No.: 9

Revision: 0

Date: January 1995

Page: 1 of 2

SECTION 9

CORRECTIVE ACTIONS PROCEDURE

The need for corrective actions may be identified by standard QC procedures, and performance and system audits. Often, the experience of chemical engineering personnel and analysts will be most valuable in alerting him/her to malfunctioning equipment or suspicious data. To promptly and uniformly identify the need for corrective action, control limits for equipment and analytical results are presented in tabular form in Table 6. 
Table 6. Control Limits and Corrective Actions for VOC Analyses in Soils and Liquids

\begin{tabular}{|c|c|c|c|c|c|c|c|}
\hline & Operation Check & Control Limits & & Frequency & Corrective Action & $\begin{array}{l}\text { Initiating } \\
\text { Corrective } \\
\text { Action }\end{array}$ & $\begin{array}{c}\text { Approving } \\
\text { Corrective } \\
\text { Action }\end{array}$ \\
\hline 1. & $\begin{array}{l}\text { Instrument Calibration (Intial): } \\
\text { Run multilevel standards } \\
\text { containing the analytes to be } \\
\text { measured to establish } \\
\text { multilevel calibration curve or } \\
\text { relative response factor (if } \\
\text { internal standard used) }\end{array}$ & $\begin{array}{l}\text { Calibration equation } \\
\text { (linear) with } \mathrm{R}^{2} \text { value of } \\
\geq 0.96 \text { or } \mathrm{RSD} \text { of relative } \\
\text { response factor } \leq 15 \%\end{array}$ & 2. & $\begin{array}{l}\text { After major instrument } \\
\text { maintenance } \\
\text { Change of analytical } \\
\text { column }\end{array}$ & $\begin{array}{l}\text { Rerun calibration curve } \\
\text { if } R^{2} \text { value of }<0.96 \text { or } \\
\text { RSD of relative } \\
\text { response factor }>15 \%\end{array}$ & Analyst & $\begin{array}{l}\text { Laboratory } \\
\text { Supervisor }\end{array}$ \\
\hline 2. & $\begin{array}{l}\text { Continuing Calibration } \\
\text { Verification of Working } \\
\text { Calibration Curve: (a } \\
\text { calibration standard is analyzed } \\
\text { to check the calibration) }\end{array}$ & $\begin{array}{l}\text { Relative response factor or } \\
\text { analyzed values predicted } \\
\text { by calibration curves } \\
\text { should not vary by more } \\
\text { than } \pm 20 \%\end{array}$ & & $\begin{array}{l}\text { Daily during the sample } \\
\text { analysis }\end{array}$ & Rerun calibration curve & Analyst & $\begin{array}{l}\text { Laboratory } \\
\text { Supervisor }\end{array}$ \\
\hline \multirow[t]{2}{*}{3.} & $\begin{array}{l}\text { Blank Samples: } \\
\text { (1) Calibration Blank }\end{array}$ & Absent & & Daily & Locate source & Analyst & $\begin{array}{l}\text { Laboratory } \\
\text { Supervisor }\end{array}$ \\
\hline & (2) Reagent Blanks & Absent & & With each sample set & Locate source & Analyst & $\begin{array}{l}\text { Laboratory } \\
\text { Supervisor }\end{array}$ \\
\hline 4. & $\begin{array}{l}\text { System Performance Check } \\
\text { Compounds (SPCC): } \\
\text { Performance check using an } \\
\text { appropriate standard mixture }\end{array}$ & $\begin{array}{l}\text { Separation of the analyte in } \\
\text { the mixture and consistency } \\
\text { in retention times. } \\
\text { Minimum RF of } 0.1 \text { for } \\
1,1 \text {-Dichloroethane, } 0.3 \text { for } \\
1,1,2,2 \text {-Tetrachloroethane }\end{array}$ & & Daily & $\begin{array}{l}\text { 1. Modify analytical } \\
\text { conditions } \\
\text { 2. Change column } \\
\text { 3. Find Source of } \\
\text { contamination }\end{array}$ & Analyst & $\begin{array}{l}\text { Laboratory } \\
\text { Supervisor }\end{array}$ \\
\hline 5. & $\begin{array}{l}\text { Quality Control Reference } \\
\text { Sample: Perform } 4 \text { samples }\end{array}$ & $\begin{array}{l}\text { Standard Deviation and } \\
\text { mean to fall within limits } \\
\text { specified in Method } 8260\end{array}$ & & Initial & $\begin{array}{l}\text { Investigate cause and } \\
\text { correct if necessary }\end{array}$ & Project Leader & $\begin{array}{l}\text { Laboratory } \\
\text { Supervisor }\end{array}$ \\
\hline 6. & $\begin{array}{l}\text { Matrix Spike and Matrix Spike } \\
\text { Duplicate }\end{array}$ & $\begin{array}{l}\text { Must obtain accuracy and } \\
\text { precision as mentioned in } \\
\text { Table } 3\end{array}$ & & $\begin{array}{l}5 \% \text { of samples or one per } \\
\text { sample set }\end{array}$ & $\begin{array}{l}\text { Run check standards for } \\
\text { QC reference sample }\end{array}$ & Project Leader & $\begin{array}{l}\text { Laboratory } \\
\text { Supervisor }\end{array}$ \\
\hline 7. & Surrogate Recovery & $\begin{array}{l}\text { As published in Method } \\
8260\end{array}$ & & $\begin{array}{l}\text { Any and all samples } \\
\text { analyzed }\end{array}$ & $\begin{array}{l}\text { Check standards, } \\
\text { calculations, instrument } \\
\text { performance, reanalyze } \\
\text { as appropriate }\end{array}$ & Project Leader & $\begin{array}{l}\text { Laboratory } \\
\text { Supervisor }\end{array}$ \\
\hline
\end{tabular}

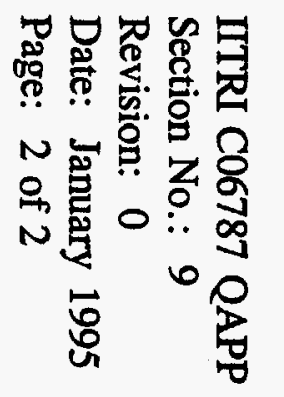


IITRI C06787 QAPP

Section No.: 10

Revision: 0

Date: January 1995

Page: 1 of 1

SECTION 10

REFERENCES

1. Demonstration Testing and Evaluation of In Situ Soil Heating, Treatability Study Work Plan (Revision 2). IITRI Project No. C06787. U.S. DoE Contract No. DE-AC05930R22160.

2. Personal Communication, dated 1-14-94. Mr. Frank Van Ryn, Martin Marietta Energy Systems, Site Programs Organization.

3. Evaluation of EPA Region IV SOP for Decontamination of Field Equipment when Sampling for Volatile Organic Compounds Published in the Proceedings of the Fifth National Outdoor Action Conference on Aquifer Restoration, Ground Water Monitoring, and Geophysical Methods. May 13-16, 1991 Las Vegas, NV. pp 601-609, Book 5.

4. Test Methods for Evaluating Solid Waste, SW-846, November 1986 Third Edition, U. S. Environmental Protection Agency. 